\title{
The 'sanction-policy' linkage from the perspective of citizens and the role of the party system
}

\author{
Andrea Fumarola ${ }^{1}$ (iD \\ Published online: 15 April 2020 \\ (c) The Author(s) 2020
}

\begin{abstract}
Research on dynamic representation stresses the effect of electoral incentives on politicians' motivation to pursue policies in line with the preferences of the majority of the citizens. However, comparative research on the so-called sanction-policy link is still limited. The present article assesses the anticipatory effect of electoral accountability on government responsiveness from the perspective of citizens across 25 European countries. Results confirm the strong positive relationship between perceptions of electoral accountability and assessments of government responsiveness. Finally, the article examines the potential moderating effect of specific party system characteristics on people's attitudes. Using multilevel models to analyse survey data from the sixth round of the European Social Survey, the study shows that the link between perceived accountability and responsiveness is conditional upon specific characteristics of the party system, namely fragmentation and volatility.
\end{abstract}

Keywords Responsiveness · Accountability · Public opinion · Party system · European social survey $\cdot$ Multilevel analysis

\section{Introduction}

Research on dynamic representation describes elected representatives as 'rational actors' that make decisions in the present with the aim to maximize their utility in the future (Erikson et al. 2002, p. 289). The rational anticipation of future electoral behaviour would trigger representatives to consider voters' preferences in the formulation of public policies (Erikson et al. 2002; Manin et al. 1999; Mansbridge

Electronic supplementary material The online version of this article (https://doi.org/10.1057/s4126 9-020-00155-7) contains supplementary material, which is available to authorized users.

Andrea Fumarola

Andrea.Fumarola@uib.no

1 Department of Comparative Politics, University of Bergen, Christies Gate 15, 5020 Bergen, Norway 
2003; Pitkin 1967). This mechanism, which assures popular control and connects citizens to governments, is described as the 'sanction-policy' linkage and constitutes the final ramification of the chain of representation (Powell 2004). However, this relationship might not be always perfectly linear, given that electoral accountability shows consistent variation across countries depending on contextual and individuallevel factors (Hobolt et al. 2013; Pérez Durán 2016; Singer 2010). Therefore, the present article investigates how strong the 'sanction-policy' linkage in Europe is, and analyses how people's perceptions of accountability influence their attitudes regarding government responsiveness. This alternative perspective would provide an effective understanding of the functioning of democratic representation. Using citizens' evaluations of democratic quality not only allows to mirror the macro-level approach employed to study the effect of electoral incentives on responsiveness in comparative perspective (Bernardi 2018; Hobolt and Klemmensen 2008; Soroka and Wlezien 2010), but it also provides a meaningful complementary 'bottom-up' perspective to it (Pickel et al. 2016).

Knowledge about the link between accountability and responsiveness across countries is still limited. Although extensive research investigates responsiveness and its determinants (Esaiasson and Wlezien 2017; Hobolt and Klemmensen 2008; Soroka and Wlezien 2010; Stimson et al. 1995; Wlezien 1995), empirical studies linking responsiveness and electoral competition across countries are still rare (Bernardi 2018; Cho 2010; Hobolt and Klemmensen 2008; Soroka and Wlezien 2010). More specifically, comparative research on the 'sanction-policy' linkage is virtually non-existent, so that the question of how electoral accountability affects responsiveness across countries has so far not been investigated. The present article seeks to contribute to the literature on political representation by assessing this relationship from the perspective of those who are the first recipients of accountability and responsiveness in representative democracies: the citizens. The study therefore compares public attitudes in 25 European democracies cross-sectionally.

The second aim of this study is to analyse how the 'sanction-policy' link varies across European countries according to specific characteristics of the party system. In representative democracies citizens traditionally voice their concerns through gatekeepers with the function to aggregate their demands and communicate them to elected officials. Political parties have, in fact, the potential to improve government's responsiveness by articulating citizens' preferences and constituting (Easton 1965; Schmitter 2000; Strøm 2000). The influence of political institutions on the link between accountability and responsiveness has been mostly analysed in single case studies or a limited number of Western countries, while only recent research analyses this topic using medium and large-N samples (Blais and Bodet 2006; Hobolt and Klemmensen 2008; Rasmussen et al. 2018; Soroka and Wlezien 2015; Wlezien and Soroka 2012). However, these studies provide contradictory evidence, mainly due to the different way in which they conceptualize representation, as either electoral representation (Golder and Stramski 2010; Powell 2000) or in between 
elections responsiveness ${ }^{1}$ (Erikson et al. 2002; Esaiasson and Narud 2013; Soroka and Wlezien 2010). Moreover, there is very little or no evidence on the potential conditional role of party system characteristics on the link between accountability and responsiveness. Because of the proven effect of specific party system characteristics-namely fragmentation, volatility, polarization-on the single components of the sanction-policy linkage, I expect these elements to condition the way in which perceptions of electoral accountability influence evaluations of government responsiveness.

I use cross-sectional data from the sixth round of the European Social Survey (ESS) to test the 'sanction-policy' link across 25 European countries. Results reveal that individual assessments of government responsiveness are positively associated with perceptions of electoral accountability. It means that citizens are more likely to evaluate their governments as responsive when they also perceive that they can hold them accountable for their performance. Moreover, analysis shows that this linkage is conditional upon specific configurations of the party system. Less fragmented and less volatile contexts are likely to strengthen the relationship between responsiveness and accountability, while no association is found for party system polarization. The analysis of individual-level attitudes confirms that responsiveness and electoral accountability are two separate but strictly related dimensions whose relationship is mediated by the party system. This implies that citizens should not underestimate the direct role of electoral control to improve government responsiveness, but also its indirect beneficial effect for the legitimacy of the whole political system.

\section{Responsiveness and electoral accountability: the 'sanction-policy' linkage}

Responsiveness is traditionally considered a crucial dimension of democratic quality because of its positive impact on the legitimacy of the political system (Bowler 2016; Dahl 1971, p. 201; Easton 1965; Esaiasson et al. 2017; Scharpf 2006). In its 'dynamic' conception, as originally developed by the seminal works of Erikson, MacKuen and Stimson (2002) and Soroka and Wlezien (2010), democratic representation is described as the response undertaken by governments in terms of policy outputs to a shift of the majority of citizens in terms of policy preferences. According to this view, public opinion functions as a 'thermostat' (Soroka and Wlezien 2010; Wlezien 1995). If citizens do not react to changes in policy, then politicians 'would have little incentive to represent what the public wants' (Wlezien 1995, p. 982). From this perspective, democratic representation would consist of a 'bottomup process' enabling citizens to influence the policy-making process (Esaiasson and Wlezien 2017).

\footnotetext{
${ }^{1}$ For a systematic review of the literature on the two ways in which representation can occur, see Arnold and Franklin (2012).
} 
The correspondence between representatives' actions and the preferences of the majority of citizens ${ }^{2}$ 'cannot depend solely on the good will of policy makers' (Powell 2004, p. 92) but it also requires effective (electoral) institutions which assure popular control and connect citizens to governments. Competitive democratic theory widely stresses the relevance of democratic procedures, arguing that the presence of competitive elections turns out to be a strong incentive for responsiveness given that parties and politicians want to be re-elected (Bartolini 1999, 2000; Dahl 1971; Manin et al. 1999; Powell 2000, 2004). Powell (2004) describes representation as a chain of causal processes in which the 'sanction-policy' linkage-resulting in responsiveness - represents the main consequence of electoral accountability. In their work on the 'between-election democracy', Esaiasson and Narud (2013) suggest that accountability could play a relevant role also during non-election times since representatives consider electoral participation the most effective instrument to influence the policy-making process. In the 'between-election mode' politicians dominate the representative relationship and the threat of future electoral sanction is the main and probably sole 'means of power' that citizens have to influence the policy-making process (Esaiasson and Narud 2013, p. 4). From this perspective electoral institutions have not only the function to select public officials, but also to control and make policies closer to public wishes (Ferejohn 1999). This conceptualization clarifies the distinction between these two important features of political representation, i.e. electoral accountability and responsiveness, which are sometimes conflated by theoretical and empirical research. ${ }^{3}$ These are distinct but strictly interrelated phenomena. When citizens have little power to sanction them for their performance, politicians would consequently be less responsive because the popular control on their actions fades away. This mechanism will inevitably reflect on citizens' perceptions of democratic representation.

\footnotetext{
2 This principle represents Dahl's (1989) idea of democracy according to which representatives should be responsive to what people want. However, responsiveness has been also conceptualized in terms of 'ideological congruence' (Golder and Stramski 2010), i.e. how citizens and governments' policy positions overlap in ideological terms according to the traditional left-right dimension (Mayne and Hakhverdian 2017). Other approaches analyse responsiveness also in terms of system support, conceived as trust in political institutions or satisfaction with democracy (Morlino and Quaranta 2014; Roberts 2014). The present article considers representation in its 'dynamic' conceptualization, namely policy responsiveness, and analyses it in terms of citizens' perceptions.

3 This is the case of the literature on 'mandate responsiveness' according to which parties offer distinct and clear policy choices to voters during electoral campaign. Once elected to power, government parties work to implement the 'mandate' received by citizens and, if they fail to do so, they should expect to be punished at the next election (Roberts 2014; Stokes 1997). However, the concept of mandate responsiveness seems to overlap the concept of 'electoral accountability' or, at least, to be one side of the same coin since both of them take place at the election time (in the past and future elections, respectively). It represents the 'prospective' component of performance voting that, together with the 'retrospective' one, constitutes the concept of electoral accountability. In this article the outcome variable is 'policy responsiveness' from the perspective of citizens which is a mechanism that take place between the elections (at present time $t$ ), clearly distinct from electoral accountability. The correspondence between citizens' preferences and policy outcomes is theorized to be influenced by the prospect of an effective mechanism of punishment (or reward) in the next elections_-at time $t+1-$ as suggested by the extensive literature on retrospective performance voting (Duch and Stevenson 2008; Key 1966).
} 
In line with Erikson and colleagues' (2002) as well as Mansbridge's (2003) concept of 'anticipatory representation', I expect electoral accountability to influence responsiveness through an 'action-reaction' mechanism involving citizens and representatives. This model considers politicians to be rational actors who make decisions at the present to maximize their utility in the future. The desire of maximizing re-election chances and anticipate the consequences of future elections, is expected to make representatives more sensitive to changes in public opinion. However, only the existence of an effective mechanism of vertical accountability would be able to generate this rational anticipation and, in turn, dynamic representation. Those institutions that allow people to identify and assign responsibility for policy decisions would, in fact, expose governments to voters' behaviour in future elections. The fear of punishment — or the ambition of reward-would persuade governments to take on policy positions that the majority of people will judge positively at the time of the next election. 'Like antelope in an open field, they cock their ears and focus their full attention on the slightest sign of danger' (Erikson et al. 2002, p. 320). This strategic shift would shape policy through the rational anticipation. Building on Friedrich's law of 'anticipated reactions' (1963), Mansbridge (2003: 517) considers political uncertainty able to shape the behaviour of representatives that, in the attempt to increase their chances of re-election, try to 'please future voters' going along with citizens' preferences. However, while it might be expected to impact government responsiveness (Dahl 1971; Miller 1983; Strøm 1992), political competition per se is not enough to ensure government responsiveness if it does not consider a broader system of performance evaluation.

This article broadens the scope by analysing the intimate connection between two dimensions of democratic quality-responsiveness and electoral accountabilityand its implication for the study of responsiveness across countries. According to Schedler (1999), electoral accountability is a multidimensional concept. It consists not only of an element of 'enforcement'-represented by the vote used to reward or punish the incumbent government—but also of a dimension of 'answerability' concerning the possibility for citizens to demand and receive information about governments' action. This second feature, in particular, turns out to be essential to guarantee high levels of government responsiveness. Research shows that information asymmetries about public affairs might cause distortion to the measures of collective opinion, reducing the capacity of government responsiveness to the citizens whose needs will be pursued unequally (Althaus 1998). Wlezien (1995, p. 981) stresses that 'democratic accountability requires that the public be reasonably well-informed about policy-making' in order to adjust its preferences and, like a thermostat, influencing government action. Hence, the multidimensional nature of the accountability concept encourages to assess its effect on political responsiveness.

However, the question concerning the way in which electoral accountability affects government responsiveness across countries has received surprisingly very little attention at the empirical level. A number of in-depth country-specific or small$\mathrm{N}$ comparative studies examines responsiveness at the aggregate-level considering different policy areas (Easton 1965; Hakhverdian 2012; Hobolt and Klemmensen 2008; Jennings 2009; Pickup and Hobolt 2015; Soroka and Wlezien 2005). With the exception of Soroka and Wlezien (2015); Wlezien and Soroka (2012), large-N 
comparative studies analysing the influence of electoral institutions on government's response to public preferences are essentially missing. This article contributes to the literature on democratic representation in two ways. It provides a comparative analysis of the relationship between electoral accountability and responsiveness in Europe while it studies this link using individual-level data. More specifically, it analyses how perceptions of electoral accountability influence attitudes regarding government responsiveness and tests whether the relationship varies across different contexts. The decision to adopt a different analytical perspective is driven by both theoretical and methodological reasons. The first reason lies on the relevance of supportive public attitudes for democratic legitimacy, conceived as both 'input-oriented' and 'output-oriented' legitimacy (Easton 1975; Scharpf 2006). These two dimensions, in fact, involve both evaluations of institutional arrangements that ensure accountable governing processes (input legitimacy) and assessments of those policies adopted in the name of the majority of people (output legitimacy). Second, the measurement of the dependent variable as individual perceptions of government responsiveness is close to the one suggested by Powell (2004, p. 102) who considers it a reliable measure given citizens' demonstrated ability to assess potential breaks in the chain of responsiveness. Third, variables based on citizens' evaluations are more likely to grasp the nuances of the concepts because they do not apply a common set of criteria as macro-level indicators do, and they are tailored on the specific cases and account for substantial and cross-country variations (Pickel et al. 2016). The last reason concerns the 'evaluative' nature of electoral accountability and responsiveness. These two relevant dimensions of democratic quality, in fact, rely consistently on the perceptions of citizens who are considered 'the only possible judges' of their own needs (Morlino 2011, p. 201). The use of individual-level data should therefore provide a relatively accurate perception of citizens' preferences. These considerations lead to formulate the first hypothesis:

Hypothesis 1 The higher the perception of accountability, the better the assessment of government responsiveness.

\section{Explaining variation in citizens' perceptions: the impact of the party system}

Building on the assumptions of institutional theory (Anderson and Singer 2008), the present article additionally aims to assess the extent to which the sanction-policy link from the perspective of the citizens varies across different institutional contexts. Comparative research on representation, conceptualized as both congruence and dynamic representation, emphasizes the role of institutions in shaping citizens' perceptions although evidence about this effect is not entirely clear. These studies are mostly focused on decentralization, concentration of powers and, above all, electoral systems to analyse, in particular, the effect of disproportionality on cabinet size (Hobolt and Klemmensen 2008; Powell 2000, 2011; Rasmussen et al. 2018; Soroka and Wlezien 2015; Wlezien and Soroka 2012). Nevertheless, the potential effect of the party system on dynamic representation has been less investigated, 
although Wlezien and Soroka (2012, p. 1425) stress that 'there are other political institutions to consider as well, including party systems themselves'. Parties and party systems are, in fact, the bedrocks of contemporary democracy given the role of representation agents at different stages of society (Morlino 2011). They serve as organizing devices for voters' political evaluations and judgements to influence the decision-making process (Borre and Katz 1973; Strøm 2000). A party system that mediates the relation between public opinion and policy is relevant for the functioning of the entire chain of representation, and in particular for the link between electoral accountability and government responsiveness (Powell 2004). I consider three features of the party system: fragmentation, volatility and polarization. Although independent of each other, these elements have been traditionally analysed in conjunction because of their capacity to capture the efficiency of the party system in a country (Quaranta 2015; Sartori 1976). While the literature has generally investigated the direct effect of the party system on accountability or responsiveness, its conditional effect on the sanction-policy link is not completely clear.

\section{Party system fragmentation}

A number of studies shows how fractionalized party systems, i.e. political systems counting a high number of parties, have the positive function to provide citizens with a varied supply of political choices (Dalton 2008; Powell 2004). The effect of this institutional variable is widely analysed in the literature on descriptive representation and ideological congruence (Blais and Bodet 2006; Powell 2000, 2011); however, evidence about its consequences for dynamic representation in comparative perspective is quite limited (Rasmussen et al. 2018; Soroka and Wlezien 2015; Wlezien and Soroka 2012). While this element seems to be doubtless beneficial for political representation, it may also represent a greater limit to the functioning of the 'sanction-policy' linkage for two, connected, reasons. ${ }^{4}$ First, recent research on between-elections representation shows that fragmentation risks to short-circuit the policy-making process because it would make it difficult for coalition governments to coordinate their action thus hampering the capacity to respond effectively to citizens' demands (Arce 2010; Soroka and Wlezien 2015; Wlezien and Soroka 2012). Second, and most important, research on electoral accountability shows the detrimental effect a higher number of parties in the system has on representation. The dispersion of preferences among several and sometimes conflicting parties risks, in fact, to hinder the formation of a feasible, credible, governing alternative (Anderson 2000; Maeda 2010). Moreover, recent research reveals that the increase in party system fragmentation has significant consequences on the composition of

\footnotetext{
${ }^{4}$ Since the article analyses the moderating effect of party system characteristics, this article considers only the broader concept of party system fragmentation. Given that electoral accountability concerns the competitive dimension of democracy, it is of primary importance to analyse the moderating effect that the number of political parties competing at elections has on it, rather than considering only the number of parliamentary or government parties.
} 
oppositions - with or without parliamentary representation-rather than governments, irrespectively of the electoral systems. While governments seem to be relatively immune to its effect, an increase in party system size exerts severe effects on the role of oppositions in established democracies. When fragmentation is high, alternation in government becomes less likely, since opposition parties are less likely to present themselves as credible alternatives to the government as 'they do not represent a cohesive set of political interests' (Best 2013, p. 337). From this perspective accountability becomes more difficult, resulting in potential negative effects on perceived responsiveness. Politicians, free from any concrete threat of replacement, would be less responsive toward citizens' preferences, preferring instead to undertake collusive behaviour (Bartolini 1999; Hobolt and Klemmensen 2008). Following these arguments, the first conditional hypothesis can thus be formulated:

Hypothesis 2 The positive effect of electoral accountability on responsiveness is stronger in less fragmented party systems.

\section{Party system volatility}

Party system volatility is traditionally considered, along with fragmentation, an important indicator of the 'quality of representation' (Arce 2010; Sartori 1976). According to the democratic theory consolidated regimes are characterized by recurring and competitive elections between a group of political parties that is essentially stable along time (Morlino 2011). Voters who face almost the same party choices would find it easier to vote on the basis of the past political performance or future policy goals, making elections an opportunity to evaluate-retrospectively-incumbent's performance or-prospectively_parties' platform for future government (Dalton et al. 2012). On the other hand, new political parties need to develop a programmatic identity and attract a stable core of voters on that basis. The low degree of organizational structure could limit to their ability to represent voters (Mair and van Biezen 2001; van Biezen 2003). Gwiazda (2015) observes that the fluidity of the party system represents a problem for electoral accountability since it hinders citizens' retrospective evaluation of political parties and elites. Conversely, low levels of volatility might have positive consequences for dynamic representation 'by facilitating legislative support for government policies; by channelling demands and conflicts through established procedures; by reducing the scope for populist demagogues to win power; and by making the democratic process more inclusive, accessible, representative, and effective' (Diamond 1997, p. xxiii). Taken together, these elements indicate a potential positive effect of party system institutionalization on the sanction-policy link. This considerations lead to formulate the following conditional hypothesis:

Hypothesis 3 The positive effect of accountability on responsiveness is stronger in less volatile, more stable party systems. 


\section{Party system polarization}

Recent research shows the negative effect of party polarization on the ideological congruence between public opinion and government because of the more extreme positions taken by parties and that this effect would be greater in proportional systems (Blais and Bodet 2006; Dalton et al. 2012; Powell, 2011). While these findings have important implication for the research on electoral representation, this article focuses on the conditional effect of party polarization on the link between perceptions of electoral accountability and assessments of government responsiveness. However, empirical studies about party polarization and dynamic representation are virtually non-existent, while recent work suggests that the effect seems to be less straightforward and might depend on the nature of the electoral system (Wlezien and Soroka 2015, p. 279). Therefore I derive my theoretical expectations from the literature on party polarization and accountability. Gelineau and Singer (2015) show that this polarization would have beneficial effects on electoral accountability because it increases the ideological cohesion of government and makes it clearly distinct from opposition. This effect might have important consequences. The increased cohesiveness of the majority party (or coalition) in the determination of public policies would make it easier for voters to associate governments with policy performance and these perceptions 'will have a greater effect on [incumbent's] fortunes' (Jones 2010, p. 325). Voters would be able, in fact, to distinguish among available alternatives and express dissatisfaction with government policies in the next election (Hellwig 2011). Stiers and Dassonneville (2019) have found similar results for multiparty contexts. Because of its beneficial effects on accountability, polarization is expected to strengthen the sanction-policy linkage with important implications for policy responsiveness. The greater 'identifiability' of policymakers would increase the potential power of sanction of voters in the next election. Consistent with the rational anticipation model, the ideological cohesion of government is expected to provide a greater incentive for coalition parties to cooperate in order to promote policies in line with the preferences of the majority. These considerations lead to the third, and last, conditional hypothesis:

Hypothesis 4 The positive effect of accountability on responsiveness is stronger in more polarized party systems.

\section{Data and methods}

To test the four hypotheses, I use individual-level data collected in the sixth round of the European Social Survey (Ferrin and Kriesi 2016) supplemented by data on national party systems collected at the country-level. The total sample is composed of 47,515 respondents. ${ }^{5}$ The 2012 ESS round is particularly suited for testing my

\footnotetext{
5 The original sample consists of 54,673 respondents from 29 countries. However, given the presence of several missing values, a standard list-wise deletion risks to cause a consistent loss of data, leading to potential biased results. I thus employ a multiple (or multivariate) imputation by chained equations
} 
expectations, as it includes questions regarding Europeans' understandings and evaluations of democracy. I include 25 out of 29 countries. ${ }^{6}$ Belgium, Bulgaria, Cyprus, Czech Republic, Denmark, Estonia, Finland, France, Germany, Great Britain, Hungary, Ireland, Iceland, Italy, Israel, Lithuania, Netherlands, Norway, Poland, Portugal, Slovakia, Slovenia, Spain, Sweden, and Switzerland. This module allows the use of different indicators to measure citizens' evaluations of democratic performance with specific questions about the single countries (Quaranta 2017). Among these indicators, the article focuses on public assessments of government responsiveness and perceptions of electoral accountability.

\section{Dependent Variable}

The dependent variable is an indicator of individual assessments of responsiveness combining two questions asking respondents whether they think it is better that the government changes policies according to what most people think ('responsiveness') or that the government sticks to its planned policies ('unresponsiveness'):

[P]lease tell me how often you think the government in [country] today changes its planned policies in response to what most people think?

[P]lease tell me how often you think the government in [country] today sticks to its planned policies regardless to what most people think

Responses to these items range from 0 to 10 , with zero indicating the case in which government 'never' adapts / sticks to its policies, and ten indicating the scenario in which it 'always' changes / sticks to its policies. I then reversed the scale of the second item, so that the new variable combining responses to the two questions range from 0 (the government is perceived as unresponsive) to 10 (the government is perceived as responsive). This methodological strategy allows to avoid a self-selection of the sample and to reduce the presence of missing values to be imputed. These two items are, in fact, preceded by a filter question asking how important government responsiveness is for democracy. On the basis of their answer, respondents are asked one of the two questions shown above. I follow the same approach adopted in recent studies using these data (Goubin 2018; Linde and Peters 2018), not only for the acknowledged reliability of the constructed variable but also for its closeness to the one suggested by Powell (2004, p. 102) who recommends the use of citizens' assessments of democracy 'as a measuring rod'. Figure 1 shows the mean values of the new dependent variable for each country included in the analysis. The

Footnote 5 (Continued)

method (using the 'mice' package for R Studio 1.1.383) to impute the relevant missing values (van Buuren and Groothuis-Oudshoorn 2011). The procedure consists in the replacement of the missing values with values obtained using a probabilistic model. Estimates are based on 5 imputed datasets with 50 iterations combined according to Rubin (1987) to account for the nested structure of the data.

6 Since we are measuring specific dimensions of the democratic quality, we consider only those countries ranked as "Free" by Freedom House's Freedom in the World annual report (2013). For this reason, Albania, Kosovo, Russia and Ukraine are not included in the sample. 


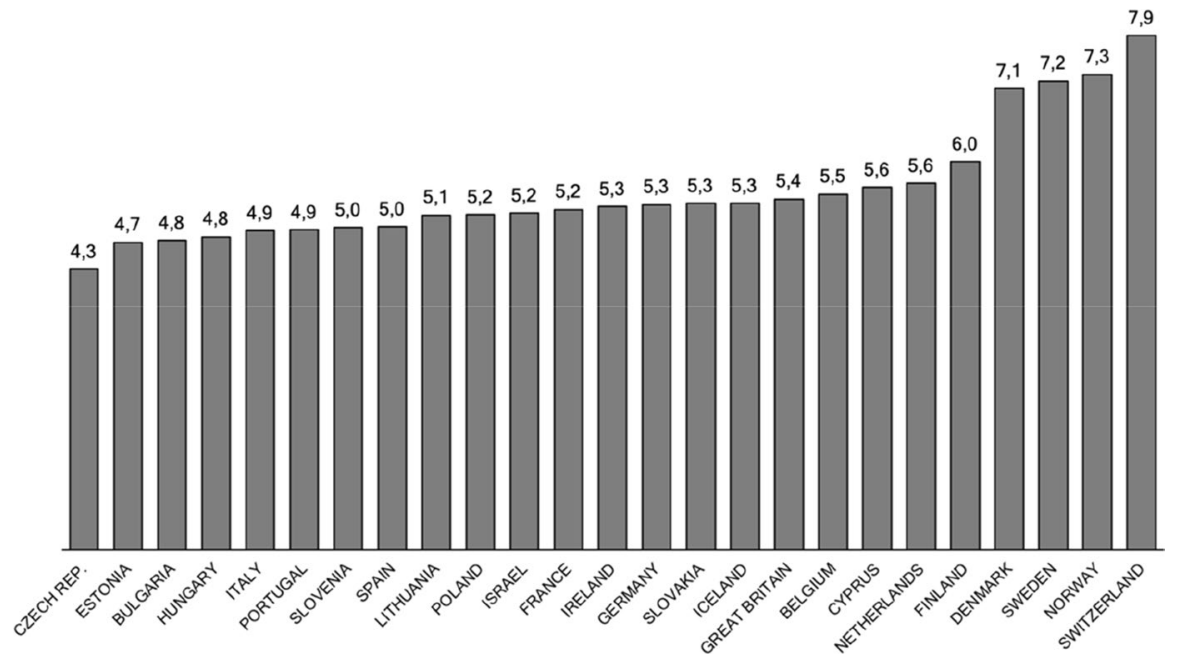

Fig. 1 Mean scores for each country of the variable 'perception of government responsiveness'. Note Perception of government responsiveness (0-10)—mean scores

countries showing the highest scores are Switzerland and the Nordics. On the other hand, Central and Eastern European countries show the lowest scores.

\section{Independent variable}

The rotating module of the ESS 6 includes also a battery of questions capturing public assessments of vertical accountability. The choice to select three specific items is driven by theoretical and methodological reasons. Electoral accountability is, in fact, a three-dimensional concept (Morlino 2011; Pickel et al. 2016; Schedler 1999). The first dimension is information, i.e. the importance of having a free and plural media system which provides citizens with alternative sources of information (Morlino 2011; Norris 2017). The second dimension is justification, which indicates the possibility for citizens to obtain valid reasons that explain government's decisions (Pérez Durán 2016; Schedler 1999). The third dimension is enforcement, i.e. the effective power of citizens to reward good or punish bad government performance (Roberts 2014). Considering its multidimensionality, the use of accurate measures to capture the concept and to reliably test its effect on government responsiveness is of paramount importance. Following recent research which has successfully tested the consistency of three items for the measurement of the underlying concept (Pickel et al. 2016; Quaranta 2017), the main explanatory variable is based on the following ones:

- In country the media provide citizens with reliable information to judge the government (0-10)

- In country the government explains its decisions to voters (0-10) 
Table 1 Confirmatory factor analysis for the latent variable 'perception of electoral accountability'

\begin{tabular}{lll}
\hline Indicators & Loadings & Uniqueness \\
\hline Election sanction when government do a bad job & 0.630 & 0.603 \\
Government explains decisions to voters & 0.795 & 0.368 \\
Media provide citizens with reliable information & 0.519 & 0.731 \\
$N$ & & 47,515 \\
\hline
\end{tabular}

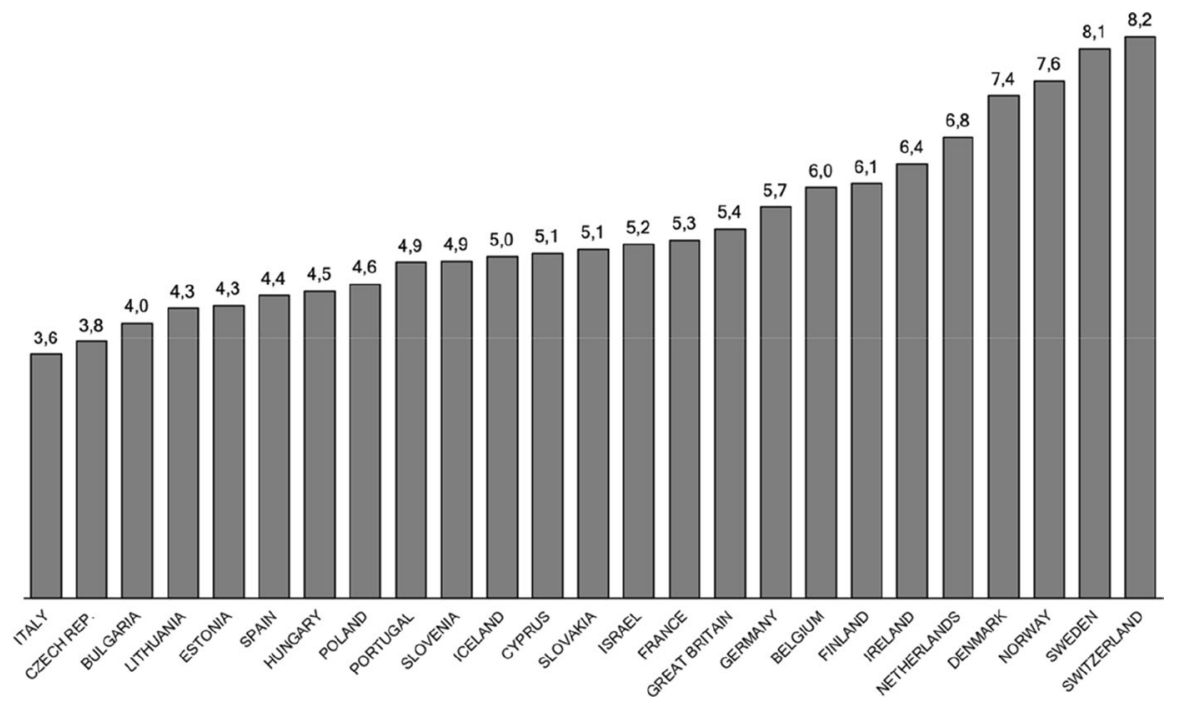

Fig. 2 Mean scores for each country of the latent variable 'perception of electoral accountability'. Note Perception of Electoral Accountability (0-10)_mean scores

- In country governing parties are punished in elections when they have done a bad job (0-10)

The first two items measure the answerability/ transparency dimension of accountability, while the third item measures the enforcement/ control dimension (Ferrin and Kriesi 2016; Morlino 2011; Schedler 1999). The theoretical relevance of the three items along with the high correlation scores suggests to combine them into one variable using Confirmatory Factor Analysis. ${ }^{7}$

\footnotetext{
${ }^{7}$ A general item measuring accountability could risk to sound very similar to responsiveness to most respondent, resulting in biased measurement and assessment of the main relationship. The battery included in this ESS round allowed instead to build (and employ) a more accurate and theoretically underpinned measure of electoral accountability. The exogeneity of the main relationship is also suggested by the rather low correlation coefficient between the two variables $(r=0.471)$.
} 
Table 1 displays the results of the latent variable model. The estimates confirm the presence of one underlying dimension and that the three items make a relevant contribution to it. The factor scores were then computed to build the new variable measuring individual perception of electoral accountability, ranging from 0 to 10 . Figure 2 shows the difference in citizens' perception of accountability presenting the mean scores calculated for each country included in the analysis. ${ }^{8}$

\section{Moderating variables}

The second part of the analysis assesses the moderating effect of three aspects of the party system on the accountability-responsiveness link. Given that the countries included in the analysis show a considerable variation in their institutional characteristics, all the moderating variables are collected at the country-level. To measure party system fragmentation, I use the Laakso and Taagepera's (1979) effective number of electoral parties (ENEP) as collected by Gallagher ${ }^{9}$ (2015). The stability of the party system is measured by the Pedersen index of net volatility ${ }^{10}$ that theoretically ranges from 0 , where no party loses votes, to 100 , where all the votes go to new parties not present in the previous election. I derived data on Western European countries from Dassonneville (2015), while data on volatility in Central and Eastern Europe are obtained by Powell and Tucker (2014). Finally, the index of polarization is the one designed by Dalton (2008) and computed by the Comparative Manifesto Project (Volkens et al. 2013). The index ranges from 0, indicating that parties have the same ideological position on the left-right scale, to 10, indicating a party system where all the parties are on the extremes of the ideological scale. ${ }^{11}$

\section{Control variables}

In order to control for differences at the country-level, the models include also the annual percentage growth rate of GDP collected in the World Development Indicators database (World Bank 2013). At the individual-level I include traditional sociodemographic controls for gender (dummy), age (in full years), education level (highest level attained), perception of income household (on a reversed four-point scale)

\footnotetext{
8 To assess the reliability of this latent variable I run a correlation test with an objective measure of accountability, the Vertical Accountability Index annually elaborated by the Varieties of Democracy (V-Dem) Institute (Coppedge et al. 2018). The result confirms a strong and highly significant correlation $\left(R=0.670^{* * *}\right)$ between the two measures.

9 In order to test its conditional effect, it is important to capture the effect of fragmentation in a broader sense, i.e. also outside the parliamentary arena. In line with previous studies analysing dynamic representation and party system fragmentation (e.g. Wlezien and Soroka 2012), the use of ENEP allows to include all the parties competing in the system rather than only those represented in parliament or in government. See Table A.3 in the Supplementary Material.

10 See Table A.3 in the Supplementary Material.

11 See Table A.3 in the Supplementary Material.
} 
along with controls for political attitudes such as winner/loser status ${ }^{12}$ (dummy), the level of political interest (reversed four-point scale), closeness to any party (dummy) and the level of political trust $(0-10) .{ }^{13}$ However, given that these controls are not the principal focus of this study they will not be discussed in the results.

\section{Methodology}

Since the analysis is based on data collected at individual- and contextual-level I employ Hierarchical Linear Models (HLM) to estimate different effects among variables with random intercepts accounting for unobserved heterogeneity among countries (Gelman and Hill 2007). Individual respondents (level 1) are nested into countries (level 2) that have different sets of parameters for the random factors, allowing intercepts and the individual-level coefficients for accountability perception to vary by nation.

\section{Results}

Table 2 presents hierarchical linear regression models (Models 1-4) in which the four hypotheses are tested. All the models estimate citizens' evaluations of government responsiveness in relation to individual perceptions of electoral accountability. Model 0 accounts for the adoption of the multilevel methodology of analysis. Model 1 presents the first hypothesis concerning the direct effect of perceptions of electoral accountability on evaluations of government responsiveness. Model 2 tests the conditional effect of party system fragmentation on the 'sanction-policy' linkage. Model 3 includes the cross-level interaction of party system volatility on the main relation. Finally, Model 4 presents the moderating effect of party system polarization on the link between accountability and responsiveness. Since the sample counts less than 30 observations at the level 2, estimations of models with more than one cross-level interaction might be problematic and confidence intervals risk to be severely biased. Following Stegmueller's (2013) recommendations, I include only one cross-level interaction per model.

The 'intercept-only' model (Model 0) confirms that the country level accounts for a substantial amount of variance in the dependent variable. The

\footnotetext{
12 Including a control for winner/loser status is particularly relevant for the analysis. As Cho (2010, p. 1655) shows, if voters feel that elections allows the party they support to end up in government, they are more likely to perceive representative institutions as responsive to their needs. On the other hand, if the parties they support lose elections, they are more likely to feel that "their voice is excluded from the decision-making process, producing dissatisfaction with political institutions".

13 For an overview and the descriptive statistics of the variables see Table A.1 and Table A.2 and in the Supplementary Material. Following an approach usually adopted in the literature (Marien and Werner 2018), political trust is measured by the latent variable obtained with the factor analysis of three items, namely 'trust in parliament', 'trust in parties', and 'trust in politicians'. Results of the latent variable model are reported in Table A.4 in the Supplementary Material.
} 


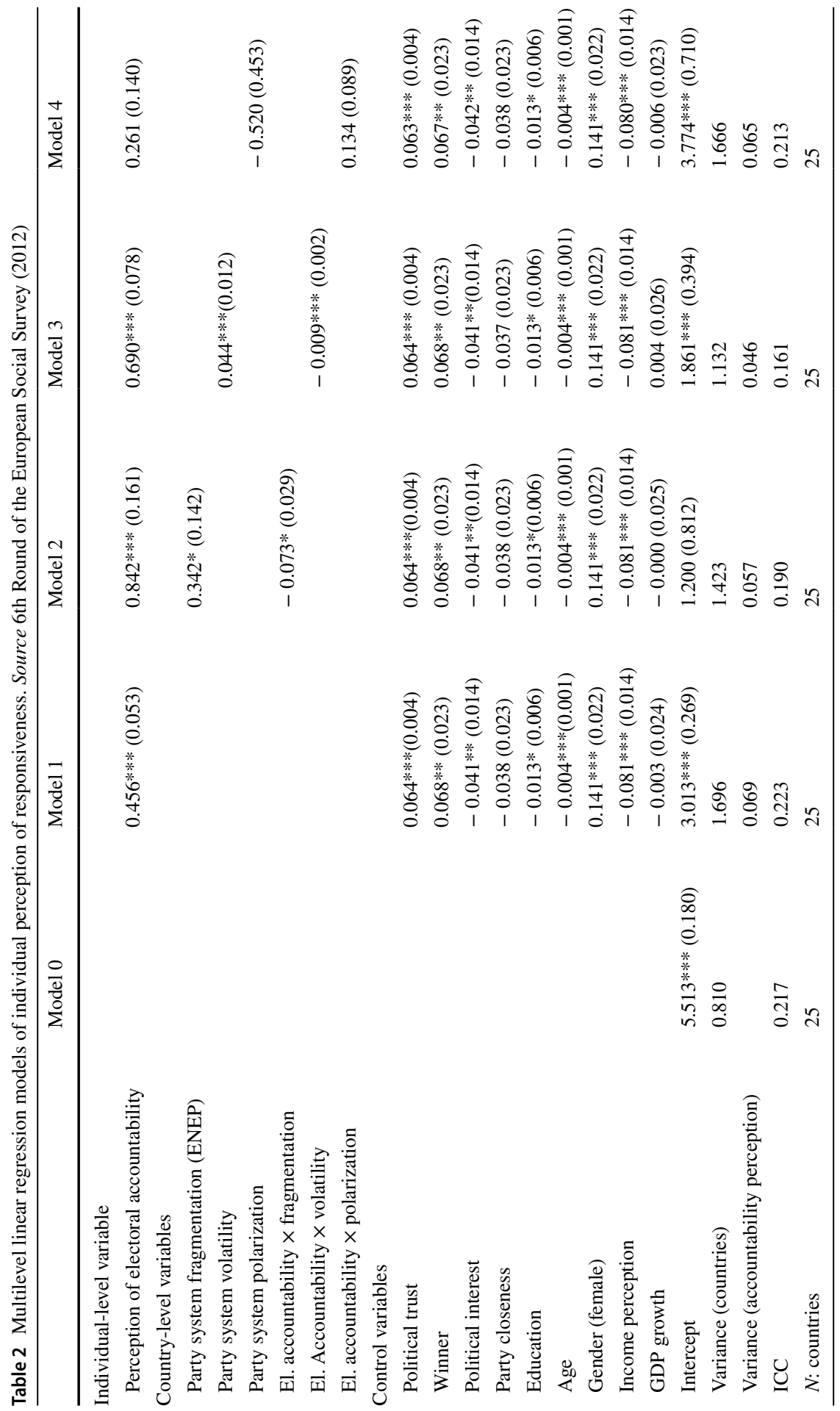




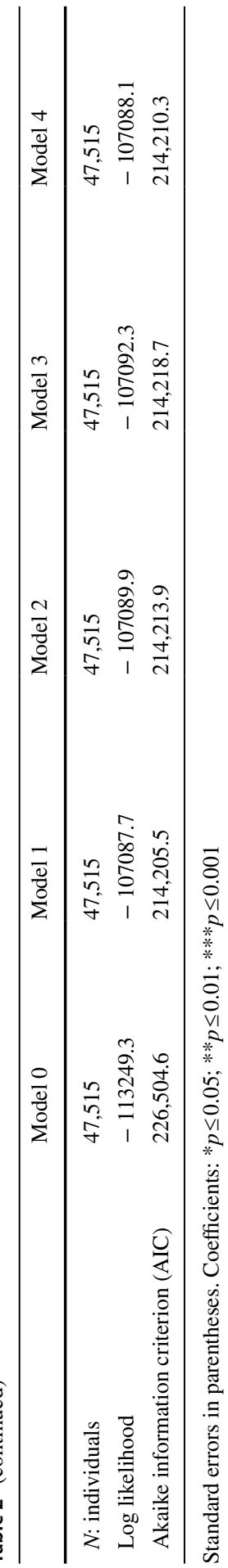

站。 
Fig. 3 Effect of electoral accountability on responsiveness depending on the level of party system fragmentation. Note The figure shows the estimated marginal effect of a one-unit change in perceptions of electoral accountability on the perceived responsiveness of government, conditional on the fragmentation of the party system. All estimates and the $95 \%$ confidence interval are based on Model 2, Table 2

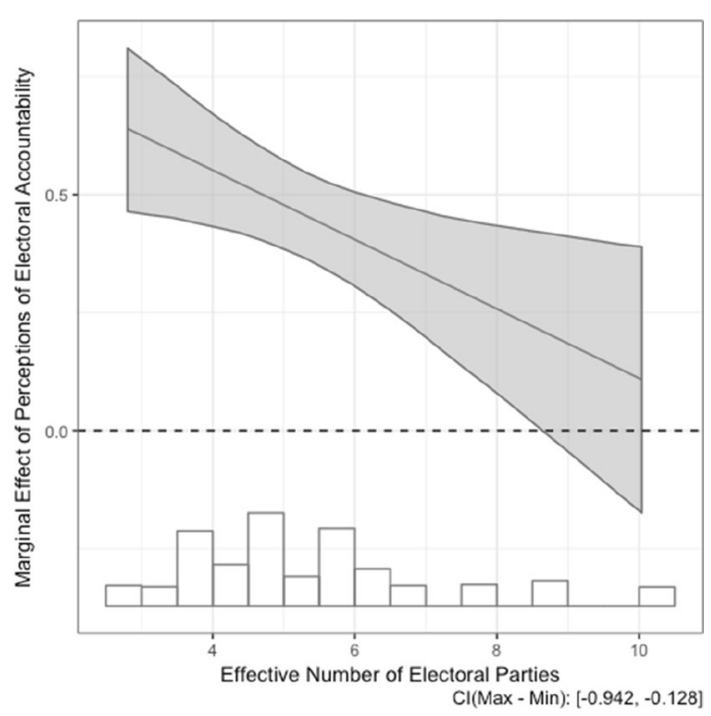

intra-class correlation coefficient (ICC) indicates that about $21 \%$ of the total variance is explained at country level, supporting the decision to perform a multilevel analysis.

I therefore run four random intercept models that control for country-specific effects to ensure that unobserved differences between countries are not driving key findings. The first model tests, from the perspective of citizens, whether a more accountable government makes it also more responsive toward their preferences $\left(\mathrm{H}_{1}\right)$. Results presented in Model 1 support the assumptions of the 'anticipatory representation' model (Erikson et al. 2002; Mansbridge 2003) according to which the threat of punishment guaranteed by the existence of an effective accountability mechanism would push governments to adopt more responsive behaviour. The coefficients indicate that if the perception of electoral accountability increases by one unit, the public perception of government responsiveness increases by 0.456 on a scale from 0 to 10 . Finally, the slope variance of the main independent variable is close to zero, indicating that the strength of the sanction-policy linkage from the perspective of citizens shows very little variation across countries. Nevertheless, the potential conditional effect of the party system on the main relationship is investigated in the three interaction models.

Model 2 tests the conditional effect of fragmentation using the Laakso and Taagepera's (1979) effective number of parties. The negative and statistically significant coefficient corroborates the second hypothesis and is confirmed by the marginal effect plotted in Fig. 3. In contexts where fragmentation is lower (e.g. Hungary or Spain) a one-unit change in the perception of electoral accountability increases the level of government responsiveness by 0.589 on a scale from 0 to 10 . Conversely, in highly fragmented party systems like Belgium or Israel, the marginal effect of accountability perception on assessments of government responsiveness is significantly reduced by almost one-sixth (to 0.101 ). 
Fig. 4 Effect of electoral accountability on responsiveness depending on the level of party system volatility. Note The figure shows the estimated marginal effect of a one-unit change in perceptions of electoral accountability on the perceived responsiveness of government, conditional on the volatility of the party system. All estimates and the $95 \%$ confidence interval are based on Model 3, Table 2
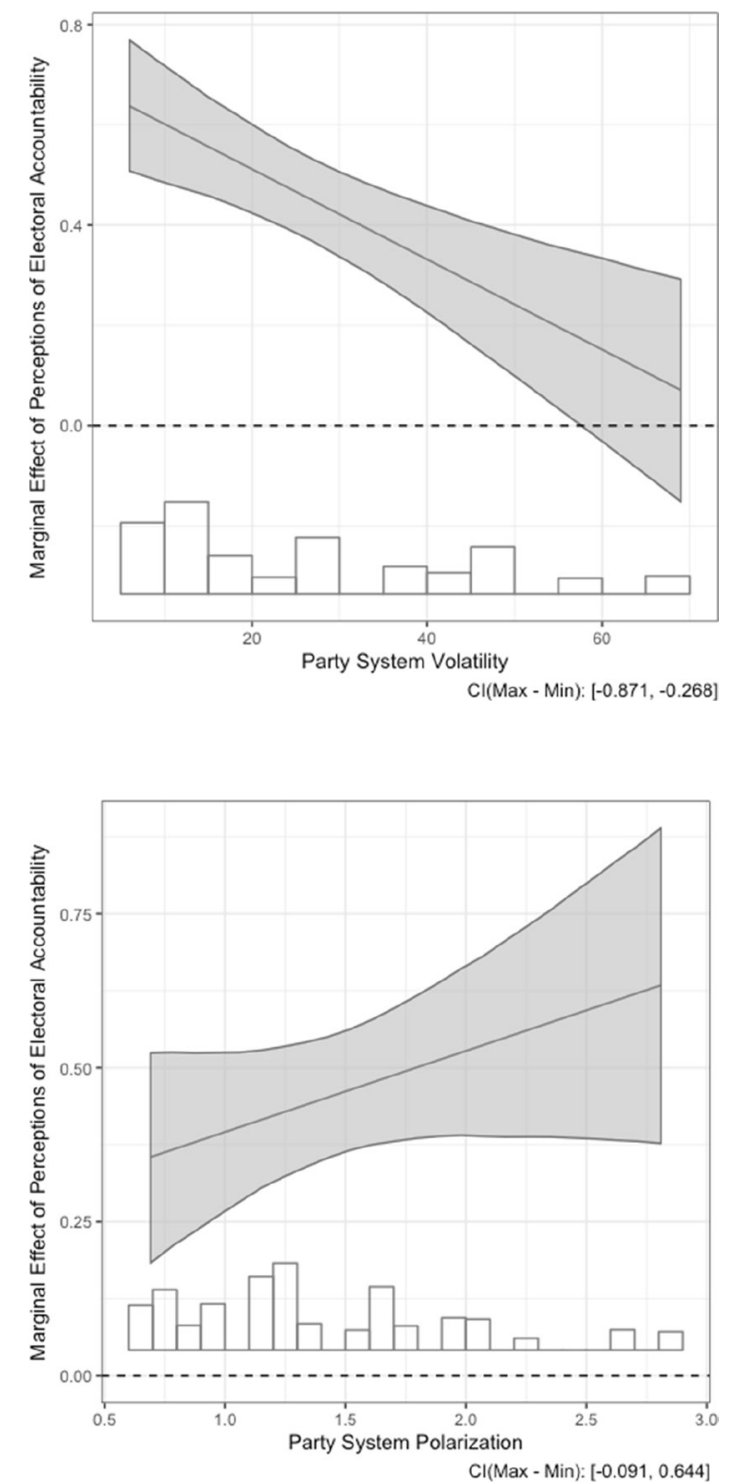

$\mathrm{Cl}(\operatorname{Max}-\mathrm{Min}):[-0.091,0.644]$
Fig. 5 Effect of electoral accountability on responsiveness depending on the level of party system polarization. Note The figure shows the estimated marginal effect of a one-unit change in perceptions of electoral accountability on the perceived responsiveness of government, conditional on the polarization of the party system. All estimates and the $95 \%$ confidence interval are based on Model 4, Table 2

The second institutional factor I expect to moderate the sanction-policy link is party system volatility. The interaction coefficient presented in Model 3 supports the third hypothesis: the positive and statistically significant effect suggests that in contexts characterized by well-institutionalized and stable party systems, accountability perceptions have a stronger positive effect on responsiveness assessments. Figure 4 presents the marginal effect of accountability perception for different levels of party system fragmentation. It shows the strong link between accountability and responsiveness evaluations in well-institutionalized party systems like Norway, Cyprus or 
the UK. Here the marginal effect of electoral accountability on responsiveness is 0.625 , while it significantly decreases by moving towards more volatile party systems (e.g. Slovakia, Slovenia or Lithuania) where a one-unit change in perception of accountability increases responsiveness' coefficient by only 0.075 .

Finally, Model 4 reports the interaction coefficient of party system polarization on the main relationship (Hypothesis 4). In this case results do not support the theoretical expectation that highly polarized party systems-i.e. where government parties are more cohesive and distinct from the opposition parties-would reinforce the sanction-policy link. Although the coefficient of the interaction is in the expected direction (positive), it fails to reach the conventional levels of significance, indicating that varying levels of party system polarization do not affect the relation between perceptions of accountability and assessments of responsiveness (see Fig. 5).

\section{Discussion and conclusion}

Moving from the extensive contribution of competitive democratic theory, established literature on dynamic representation, and emerging research analysing electoral incentives on policy responsiveness, this article aimed to investigate the effect of public perceptions of accountability on assessments of government responsiveness across 25 European countries. The main argument builds on the thermostat model of representation (Soroka and Wlezien 2010; Wlezien 1995) and the rational anticipation theory (Erikson et al. 2002; Mansbridge 2003), according to which governments respond to changes in citizens' preferences in order to maximize their chances of re-election. The article employed individual assessments of vertical accountability and government responsiveness to analyse this mechanism across different countries and provide an understanding of the functioning of democratic representation in practice.

The analysis confirmed the existence of a 'sanction-policy link' from the perspective of citizens, showing that public perceptions of government responsiveness are influenced by the extent to which people perceive the government as accountable. The effect is consistent across both established and relatively young European democracies with very different characteristics, an element that allows to generalize findings and increases their validity. The use of survey data to analyse dynamic representation has several merits. First, it provides a significant complementary perspective to the traditional approach adopted to study the effect of electoral incentives on policy responsiveness (Bernardi 2018; Erikson et al. 2002; Hobolt and Klemmensen 2008; Mansbridge 2003; Soroka and Wlezien 2010). The analysis of citizens' attitudes, in fact, supports the indication that the threat of alternation and replacement of unresponsive representatives would spur governments to adopt an 'anticipatory behaviour' and act responsively toward citizens' preferences. Moreover, the analysis of citizens' perceptions allows to understand directly how successful are the (policy) measures put in place by governments and what makes people satisfied with them. This is extremely relevant, given that extensive research shows the importance of supportive attitudes to achieve and strengthen democratic legitimacy (Scharpf 2006). 
Building on the recent literature about the effect of political institutions on dynamic representation (Hobolt and Klemmensen 2008; Rasmussen et al. 2018; Soroka and Wlezien 2015; Wlezien and Soroka 2012), the article analysed whether and how specific characteristics of the party system moderate the sanction-policy link from the perspective of citizens. The sixth round of the European Social Survey collects data from 25 democracies showing a very high degree of systemic variation in terms of number of parties and levels of party polarization or volatility. Results from multilevel analysis support two of the three theoretical expectations. While no evidence is found about the effect of polarization on the sanction-policy link, the relationship between perception of accountability and assessment of responsiveness turns out to be weaker in presence of highly fragmented and volatile party systems. In line with Wlezien and Soroka's (2012) findings at the aggregate-level, the present study shows that a great number and diversity of parties in the system is detrimental for representation in between elections. In highly fragmented party systems the positive effect of accountability on responsiveness decreases, weakening the sanction-policy link from the perspective of citizens. Beside this, the analysis has also revealed that higher levels of party system volatility could moderate dynamic representation by weakening perceptions of electoral accountability and, in turn, evaluations of democratic responsiveness. This is particularly relevant in the light of a recent process of 'de-institutionalization' investing Western European party systems and that gradually makes them closer to the traditionally more volatile Central and Eastern European neighbours (Emanuele et al. 2018). These results suggest the existence a potential representation deficit triggered by dysfunctional party systems, and that could have negative consequences for the legitimacy of the democratic system.

In conclusion, the present article has provided additional support to the anticipatory representation and thermostatic models of representation by analysing, for the first time, this mechanism from the perspective of citizens. Moreover, the study of the conditional effect of the party system across several European countries represents a contribution to the emergent research agenda investigating the potential effect of political institutions on dynamic representation.

Acknowledgements The author acknowledges support from the Trond Mohn Foundation (TMF) Grant No. 811309. A previous version of this work was presented at the 'Political Inequality and How Representative Democracy Functions' workshop at the Ash Center of the Harvard Kennedy School. The author thanks all the participants and, in particular, Yvette Peters for her invaluable comments and suggestions on previous versions of this article.

\section{Compliance with ethical standards}

Conflict of interest On behalf of all authors, the corresponding author states that there is no conflict of interest.

Open Access This article is licensed under a Creative Commons Attribution 4.0 International License, which permits use, sharing, adaptation, distribution and reproduction in any medium or format, as long as you give appropriate credit to the original author(s) and the source, provide a link to the Creative Commons licence, and indicate if changes were made. The images or other third party material in this article are included in the article's Creative Commons licence, unless indicated otherwise in a credit line to the 
material. If material is not included in the article's Creative Commons licence and your intended use is not permitted by statutory regulation or exceeds the permitted use, you will need to obtain permission directly from the copyright holder. To view a copy of this licence, visit http://creativecommons.org/licen ses/by/4.0/.

\section{References}

Althaus, S.L. 1998. Effects in collective preferences. The American Political Science Review 92 (3): 545-558.

Anderson, C.J. 2000. Economic voting and political context. Electoral Studies 19: 151-170.

Anderson, C.J., and M.M. Singer. 2008. The sensitive left and the impervious right: Multilevel models and the politics of inequality, ideology, and legitimacy in Europe. Comparative Political Studies 41 (4-5): 564-599. https://doi.org/10.1177/0010414007313113.

Arce, M. 2010. Parties and social protest in Latin America's neoliberal era. Party Politics 16 (5): 66-82.

Arnold, C., and M.N. Franklin. 2012. Introduction: Issue congruence and political responsiveness. West European Politics 35 (6): 1217-1225. https://doi.org/10.1080/01402382.2012.713741.

Bartolini, S. 1999. Collusion, competition and democracy, Part I. Journal of Theoretical Politics 11 (4): $435-470$.

Bartolini, S. 2000. Collusion, competition and democracy, Part II. Journal of Theoretical Politics 12 (1): 33-65.

Bernardi, L. 2018. Policy Responsiveness and electoral incentives: A (Re) assessment. Political Behavior. https://doi.org/10.1007/s11109-018-9490-4.

Best, R.E. 2013. How party system fragmentation has altered political opposition in established democracies. Government and Opposition 48 (3): 314-342. https://doi.org/10.1017/gov.2013.16.

Blais, A., and M.A. Bodet. 2006. Does proportional representation foster closer congruence between citizens and policy makers? Comparative Political Studies 39 (10): 1243-1262.

Borre, O., and R. Katz. 1973. Party identification and its motivational base in a multiparty system: A study of the Danish General Election of 1971. Scandinavian Political Studies 8 (A8): 60-111.

Bowler, S. 2016. Trustees, delegates, and responsiveness in comparative perspective. Comparative Political Studies 50 (6): 766-793. https://doi.org/10.1177/0010414015626447.

Cho, W. 2010. Citizens' perceptions of government responsiveness in Africa: Do Electoral systems and ethnic diversity matter? Comparative Political Studies 43 (12): 1650-1674. https://doi. org/10.1177/0010414010374019.

Coppedge, M., Gerring, J., Knutsen, C. H., Lindberg, S. I., Skaaning, S.-E., Teorell, J., ... Daniel, Z. (2018). "V-Dem Codebook v8" Varieties of Democracy (V-Dem) Project.

Dahl, R. 1971. Poliarchy: Participation and Opposition. New Haven: Yale University Press.

Dahl, R. 1989. Democracy and its critics. New Haven: Yale University Press.

Dalton, R.J. 2008. The quantity and quality of party system. Comparative Political Studies 41 (7): 899-920.

Dalton, R.J., D.M. Farrell, and I. McAllister. 2012. Political parties and democratic linkage: How parties organize democracy. Oxford: Oxford University Press.

Dassonneville, R. 2015. Net volatility in Western Europe 1950-2014. Leuven: Centre for Citizenship and Democracy.

Diamond, L. 1997. Introduction: In search of consolidation. In Consolidating the third wave democracies, ed. L. Diamond, M.F. Plattner, Y.H. Chu, and H.M. Tien. Baltimore: Johns Hopkins University Press.

Duch, R.M., and R.T. Stevenson. 2008. The economic vote: How political and economic institutions condition election results. New York: Cambridge University Press.

Easton, D. 1965. A framework for political analysis. Englewood Cliffs: Prentice-Hall.

Easton, D. 1975. A re-assessment of the concept of political support. British Journal of Political Science 5 (4): 435-457.

Emanuele, V., A. Chiaramonte, and S. Soare. 2018. Does the Iron curtain still exist? The convergence in electoral volatility between eastern and western Europe. Government and Opposition. https://doi. org/10.1017/gov.2018.25. 
Erikson, R.S., M.B. Mackuen, and J.A. Stimson. 2002. The macro polity. New York: Cambridge University Press.

Esaiasson, P., M. Gilljam, and M. Persson. 2017. Responsiveness beyond policy satisfaction: Does it matter to citizens? Comparative Political Studies 50 (6): 739-765. https://doi.org/10.1177/0010414015 626445.

Esaiasson, P., and M. Narud (eds.). 2013. Between-election democracy: The representative relationship after election day. Colchester: ECPR Press.

Esaiasson, P., and C. Wlezien. 2017. Advances in the study of democratic responsiveness: An introduction. Comparative Political Studies 50 (6): 699-710. https://doi.org/10.1177/0010414016633226.

Ferejohn, J. 1999. Accountability and authority: Toward a theory of political accountability. In Democracy, accountability, and representation, ed. A. Przeworski, B. Manin, and S.C. Stokes, 131-153. Cambridge: Cambridge University Press.

Ferrin, M., and H. Kriesi (eds.). 2016. How europeans view and evaluate democracy. Oxford: Oxford University Press.

Freedom House. (2013). Freedom in the world. Retrieved from New York.

Friedrich, C.J. 1963. Man and his government. New York: McGraw Hill.

Gallagher, M. (2015). Electoral Indices dataset. Retrieved from https://www.tcd.ie/Political_Science/staff /michael_gallagher/ElSystems/index.php.

Gelineau, F., and M.M. Singer. 2015. The economy and incumbent support in Latin America. In The Latin American voter, ed. M.M. Singer, R.E. Carlin, and E.J. Zechmeister, 281-299. Ann Arbor, MI: University of Michigan Press.

Gelman, A., and J. Hill. 2007. Data analysis using regression and multilevel hierarchical models. Cambridge: Cambridge University Press.

Golder, M., and J. Stramski. 2010. Ideological congruence and electoral institutions. American Journal of Political Science 54 (1): 90-106.

Goubin, S. 2018. Economic inequality, perceived responsiveness and political trust. Acta Politica. https:// doi.org/10.1057/s41269-018-0115-z.

Gwiazda, A. 2015. Democracy in Poland: Representation, participation competition and accountability since 1989. London: Routledge.

Hakhverdian, A. 2012. The causal flow between public opinion and policy: Government responsiveness, leadership, or counter movement? West European Politics 35 (6): 1386-1406.

Hellwig, T. 2011. Context, political information, and performance voting. In Citizens, context, and choice: How context shapes citizens' electoral choices, ed. R.J. Dalton and C. Anderson. Oxford: Oxford University Press.

Hobolt, S., and R. Klemmensen. 2008. Government responsiveness and political competition in comparative perspective. Comparative Political Studies 41 (5): 309-337.

Hobolt, S., J. Tilley, and S. Banducci. 2013. Clarity of responsibility: How government cohesion conditions performance voting. European Journal of Political Research 52 (2): 164-187. https://doi.org/1 0.1111/j.1475-6765.2012.02072.x.

Jennings, W. 2009. The public thermostat, political responsiveness and error-correction: Border control and asylum in Britain, 1994-2007. British Journal of Political Science 39 (4): 309-337.

Jones, D.R. 2010. Polarization and electoral accountability in the US congress. American Journal of Political Science 54 (2): 323-337.

Key, V.O. 1966. The responsible electorate: Rationality in presidential voting 1936-1960. Cambridge: Harvard University Press.

Laakso, M., and R. Taagepera. 1979. Effective number of parties. Comparative Political Studies 12 (1): $3-27$.

Linde, J., and Y. Peters. 2018. Responsiveness, support, and responsibility: How democratic responsiveness facilitates responsible government. Party Politics. https://doi.org/10.1177/1354068818763986.

Maeda, K. 2010. Divided we fall: Opposition fragmentation and the electoral fortunes of governing parties. British Journal of Political Science 40 (2): 419-434.

Mair, P., and I. van Biezen. 2001. Party membership in twenty European democracies, 1980-2000. Party Politics 7 (1): 5-21.

Manin, B., A. Przeworski, and S.C. Stokes. 1999. Elections and representation. In Democracy, accountability, and representation, ed. A. Przeworski, S.C. Stokes, and B. Manin. Cambridge: Cambridge University Press.

Mansbridge, J. 2003. Rethinking representation. American Political Science Review 97 (4): 515-528. 
Marien, S., and H. Werner. 2018. Fair treatment, fair play?: The relationship between fair treatment perceptions, political trust and compliant and cooperative attitudes cross-nationally. European Journal of Political Research. https://doi.org/10.1111/1475-6765.12271.

Mayne, Q., and A. Hakhverdian. 2017. Ideological congruence and citizens satisfaction: Evidence from 25 advanced democracies. Comparative Political Studies 50 (6): 822-849.

Miller, D. (1983). The competitive model of democracy. In D. Graeme (Ed.), Democratic Theory and practice. Cambridge: Cambridge University Press.

Morlino, L. 2011. Changes for democracy: Actors, structures, processes. Oxford: Oxford University Press.

Morlino, L., and M. Quaranta. 2014. The non-procedural determinants of responsiveness. West European Politics 37 (2): 331-360. https://doi.org/10.1080/01402382.2014.887878.

Norris, P. 2017. Electoral transparency, accountability and integrity. In Election watchdogs: Transparency, accountability and integrity, ed. P. Norris and A. Nai. New York: Oxford University Press.

Pérez Durán, I. 2016. Accountability from the perspective of the forum: Citizens' attitudes towards accountability in Europe. West European Politics 39 (4): 835-858. https://doi.org/10.1080/01402 382.2015.1105597.

Pickel, S., W. Breustedt, and T. Smolka. 2016. Measuring the quality of democracy: Why include the citizens' perspective? International Political Science Review 37 (5): 645-655. https://doi. org/10.1177/0192512116641179.

Pickup, M., and S. Hobolt. 2015. The conditionality of the trade-off between government responsiveness and effectiveness: The impact of minority status and polls in the Canadian House of Commons. Electoral Studies 40: 517-530.

Pitkin, H.F. 1967. The concept of representation. Berkeley: University of California Press.

Powell, E.N., and J.A. Tucker. 2014. Revisiting electoral volatility in post-communist countries: New data, new results and new approaches. British Journal of Political Science 44 (1): 123-147.

Powell, G.B. 2000. Elections as instruments of democracy: Majoritarian and proportional visions. New Haven: Yale University Press.

Powell, G.B. 2004. The chain of responsiveness. Journal of Democracy 15 (4): 91-105. https://doi. org/10.1353/jod.2004.0070.

Powell, G.B. 2011. Party polarization and the ideological congruence of governments. In Citizens, context, and choice: How context shapes citizens' electoral choices, ed. R.J. Dalton and C. Anderson. Oxford: Oxford University Press.

Quaranta, M. 2015. Political protest in Western Europe: Exploring the role of context in political action. Cham: Springer.

Quaranta, M. 2017. How citizens evaluate democracy: An assessment using the European Social Survey. European Political Science Review. https://doi.org/10.1017/s1755773917000054.

Rasmussen, A., S. Reher, and D. Toshkov. 2018. The opinion-policy nexus in Europe and the role of political institutions. European Journal of Political Research. https://doi.org/10.1111/1475-6765.12286.

Roberts, A. 2014. The quality of democracy in eastern Europe. New York: Cambridge University Press.

Rubin, D. 1987. Multiple imputation for nonresponse in surveys. New York: Wiley.

Sartori, G. 1976. Parties and party systems: A framework for analysis. Colchester: ECPR Press.

Scharpf, F. W. (2006). Problem-solving effectiveness and democratic accountability in the EU. Political Science Series Working Paper. Institute for Advanced Studies, Vienna. Retrieved from https://aei. pitt.edu/6097/1/pw_107.pdf.

Schedler, A. 1999. Conceptualizing accountability. In The self-restraining state: power and accountability in new Democracies, ed. A. Schedler, L. Diamond, and M.F. Plattner. London: Lynne Rienner.

Schmitter, P. 2000. How to democratize the European Union... and why bother?. Lanham: Rowman \& Littlefield.

Singer, M.M. 2010. Who says "It's the economy"? Cross-national and cross-individual variation in the salience of economic performance. Comparative Political Studies 44 (3): 284-312. https://doi. org/10.1177/0010414010384371.

Soroka, S.N., and C. Wlezien. 2005. Opinion-policy dynamics: Public preferences and public expenditures in the United Kingdom. British Journal of Political Science 35: 665-689.

Soroka, S.N., and C. Wlezien. 2010. Degrees of democracy: Politics, public opinion, and policy. Cambridge: Cambridge University Press.

Soroka, S.N., and C. Wlezien. 2015. The majoritarian and proportional visions and democratic responsiveness. Electoral Studies 40: 539-547. https://doi.org/10.1016/j.electstud.2015.07.004. 
Stegmueller, D. 2013. How many countries for multilevel modeling? A comparison of frequentist and Bayesian approaches. American Journal of Political Science 57 (3): 748-761. https://doi. org/10.1111/ajps.12001.

Stiers, D., and R. Dassonneville. 2019. Retrospective voting and the polarization of available alternatives. Canadian Journal of Political Science. https://doi.org/10.1017/S0008423919000556.

Stimson, J.A., M.B. Mackuen, and R.S. Erikson. 1995. Dynamic representation. American Political Science Review 89 (3): 543-565. https://doi.org/10.2307/2082973.

Stokes, S.C. 1997. Democratic accountability and policy change: Economic policy in Fujimori's Peru. Comparative Politics 29 (2): 209-226. https://doi.org/10.2307/422080.

Strøm, K. 1992. Democracy as political competition. American Behavioral Scientist 35 (4-5): 375-396.

Strøm, K. 2000. Delegation and accountability in parliamentary democracies. European Journal of Political Research 37: 261-289.

van Biezen, I. 2003. Political parties in new democracies. Party organization in southern and east-central Europe. Houndmills: Palgrave MacMillan.

van Buuren, S., and K. Groothuis-Oudshoorn. 2011. mice: Multivariate imputation by chained equations in R. Journal of Statistical Software 45 (3): 1-67.

Volkens, A., Lehmann, P., Merz, N., Regel, S., \& Werner, A. (2013). The Manifesto data Collection. From Manifesto Project (MRG/CMP/MARPOR). Wissenschaftszentrum Berlin fur Sozialforschung.

Wlezien, C. 1995. The public as thermostat: Dynamics of preferences for spending. American Journal of Political Science 39 (4): 981-1000. https://doi.org/10.2307/2111666.

Wlezien, C., and S.N. Soroka. 2012. Political institutions and the opinion-policy link. West European Politics 35 (6): 1407-1432. https://doi.org/10.1080/01402382.2012.713752.

Wlezien, C., and S.N. Soroka. 2015. Electoral systems and opinion representation. Representation 51 (3): 273-285. https://doi.org/10.1080/00344893.2015.1111928.

World Bank. (2013). World development indicators and global development finance. Retrieved from https ://databank.worldbank.org.

Publisher's Note Springer Nature remains neutral with regard to jurisdictional claims in published maps and institutional affiliations.

Andrea Fumarola is Postdoctoral Research Fellow in the Department of Comparative Politics of the University of Bergen. He was Visiting research fellow at the University of Sydney with the Electoral Integrity Project and Visiting researcher at the GESIS Eurolab in Cologne. His research focuses on comparative voting behaviour and representation, more specifically on electoral accountability and responsiveness in a comparative perspective. 